\title{
Interrogation of highly structured RNA with multicomponent deoxyribozyme probes at ambient temperatures
}

\author{
ADAM J. REED, RYAN J. SAPIA, CHARLES DOWIS, SHEILA SOLAREZ, and YULIA V. GERASIMOVA \\ Chemistry Department, University of Central Florida, Orlando, Florida 32765, USA
}

\begin{abstract}
Molecular analysis of RNA through hybridization with sequence-specific probes is challenging due to the intrinsic ability of RNA molecules to form stable secondary and tertiary structures. To overcome the energy barrier toward the probe-RNA complex formation, the probes are made of artificial nucleotides, which are more expensive than their natural counterparts and may still be inefficient. Here, we propose the use of a multicomponent probe based on an RNA-cleaving deoxyribozyme for the analysis of highly structured RNA targets. Efficient interrogation of two native RNA from Saccharomyces cerevisiae - a transfer RNA (tRNA) and 18S ribosomal RNA (rRNA)—was achieved at ambient temperature. We achieved detection limits of tRNA down to $\sim 0.3 \mathrm{nM}$, which is two orders of magnitude lower than that previously reported for molecular beacon probes. Importantly, no probe annealing to the target was required, with the hybridization assay performed at $37^{\circ} \mathrm{C}$. Excess of nonspecific targets did not compromise the performance of the probe, and high interrogation efficiency was maintained by the probes even in complex matrices, such as cell lysate. A linear dynamic range of 0.3-150 nM tRNA was demonstrated. The probe can be adapted for differentiation of a single mismatch in the tRNA-probe complex. Therefore, this study opens a venue toward highly selective, sensitive, robust, and inexpensive assays for the interrogation of biological RNA.
\end{abstract}

Keywords: structured RNA; nucleic acid analysis; tRNA; rRNA; deoxyribozyme; multicomponent probes

\section{INTRODUCTION}

As our knowledge of the biological functions of ribonucleic acids (RNA) increases, so does the importance of their sequence-specific detection. RNA has been implicated in many biological functions, including the storage, transfer, and interpretation of genetic information, as well as control of gene expression. RNA analysis has proven an invaluable tool for understanding the epidemiology and pathogenesis of diseases, regulation of cellular response to therapy and drug efficiency, and in clinical disease diagnostics. Interrogation of RNA targets with a known primary structure using complementary DNA oligonucleotides is one of the approaches used for RNA analysis (Brown et al. 2004; Simon 2013; Fang et al. 2018; Ranasinghe et al. 2018). However, the inherent ability of RNA molecules to fold into complex three-dimensional shapes because of base-pair interactions makes interrogation of natural RNA challenging and limits molecular analysis to the easily accessible loop and bulge RNA regions

Corresponding author: yulia.gerasimova@ucf.edu

Article is online at http://www.rnajournal.org/cgi/doi/10.1261/rna. 074864.120 .
(Herschlag et al. 2018). Indeed, scrupulous and costly analysis of the target accessibility is generally required to select an optimal design of a conventional hybridization probe (e.g., molecular beacon probe [MBP]) (Rhee et al. 2008; Li et al. 2017). The intrinsic stem in the MBP structure stabilizes the probe, thus disfavoring its interactions with a stem-loop folded targeted fragment to form a probe-target complex (Fig. 1A). Alternatively, the probes can be made of unnatural nucleic acid analogs-L-DNA (Kim et al. 2007), locked nucleic acids (LNAs) (Wang et al. 2005), and peptide nucleic acids (PNAs) (Petersen et al. 2004), which interact with DNA/RNA targets with higher affinities than those of natural DNA oligomers. Unfortunately, high cost makes their use for routine RNA analysis less appealing.

A promising tool for nucleic acid analysis using unmodified DNA oligonucleotides is multicomponent hybridization probes (MHPs) (Kolpashchikov 2010). The modular

(c) 2020 Reed et al. This article is distributed exclusively by the RNA Society for the first 12 months after the full-issue publication date (see http://rnajournal.cshlp.org/site/misc/terms.xhtml). After 12 months, it is available under a Creative Commons License (Attribution-NonCommercial 4.0 International), as described at http://creativecommons.org/ licenses/by-nc/4.0/. 
A

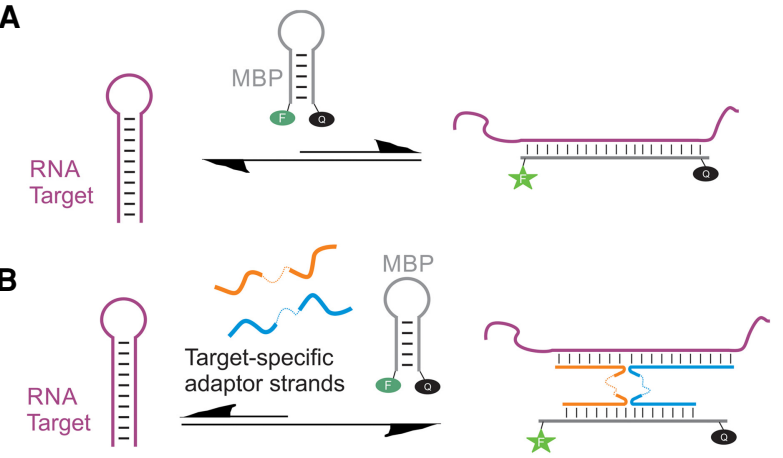

FIGURE 1. Detection of structured nucleic acids using molecular beacon probe (MBP)-based approaches. (A) Interaction of a stem-loop folded MBP with a structured nucleic acid target is thermodynamically unfavored. (B) Two target-specific adaptor strands of the MBP-based MHP serve to unwind the target's secondary structure and shift the equilibrium toward the high-fluorescent probe-target complex. The dotted curves represent triethylene glycol linkers in the adaptor strands.

MHP design allows for allocation of each probe component to a given function (Grimes et al. 2010; Nguyen et al. 2011; Nedorezova et al. 2019). For example, such probes can be highly selective and, at the same time, able to tightly bind a specific nucleic acid target, which is generally unattainable with conventional hybridization probes (Demidov and Frank-Kamenetskii 2004). This property of MHP can be utilized to interrogate highly structured natural RNA targets (Nguyen et al. 2011; Li et al. 2012; Gentry et al. 2015; Gerasimova et al. 2015). For example, an MBP-based tricomponent probe was able to efficiently interrogate and, at the same time, discriminate single-nucleotide substitutions (SNSs) in a target containing a stem of up to $13 \mathrm{bp}$ (Nguyen et al. 2011). This was achieved due to the presence of two target-specific strands of the probe that served as adaptors between the target and MBP reporter (Fig. 1B). A similar approach was later proven successful for analysis of SNSs positioned in the middle of a stable stem using a solid-phase-conjugated MHP (Sun et al. 2019).

In this work, we demonstrate the advantages of MHPs by challenging their ability to interrogate a highly structured and heavily modified natural RNA target—a transfer RNA (tRNA) molecule. Even though the nucleotide sequence is variable among different tRNAs, the secondary structure of tRNA is well-conserved. According to the cloverleaf model, it consists of the acceptor stem, the variable loop, and three hairpin elements (the D-arm, the anticodon arm, and the TYC-arm) (Robertus et al. 1974). The loops are involved in tertiary interactions (Shi and Moore 2000), which add to the great thermal stability of the L-shaped native tRNA molecule and resistance to unfolding, and further disfavors tRNA interactions with complementary probe sequences. Even though MBPs that can detect specific tRNA sequences have been previously reported (Li et al. 2012; Miyoshi et al. 2019), it required designing and testing multiple expensive MBPs to find the one that achieves moderate performance. The optimized MBPs exhibited detection limits of 23-27 nM with nonmodified tRNA transcripts as targets, which are known to be less thermodynamically stable than mature tRNA (Serebrov et al. 1998). These detection limits increase at least 20-fold the values reported for unstructured targets (Kolpashchikov 2012). This is not surprising because of the high thermodynamic stability of the tRNA targets and stoichiometric probe-target binding. Here, we used a split deoxyribozyme (sDz) probe for sensitive and cost-efficient tRNA interrogation. The probe is made of two DNA strands $\left(D z_{a}\right.$ and $\left.D z_{b}\right)$, each containing half of the catalytic core of the RNA-cleaving deoxyribozyme 10-23 (Fig. 2A; Santoro and Joyce 1997) elongated with the fragments complementary to the abutting positions of the tRNA target, as well as the fragments recognizing a fluorogenic substrate $\left(F_{\text {sub }}\right)$ (Fig. 2B; Kolpashchikov 2007; Gerasimova et al. 2010; Mokany et al. 2010). The substrate is labeled with a fluorophore and a quencher at the opposite sides of the cleavage site. Target-initiated

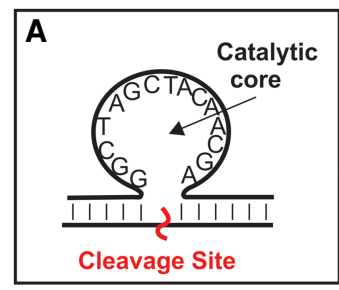

B

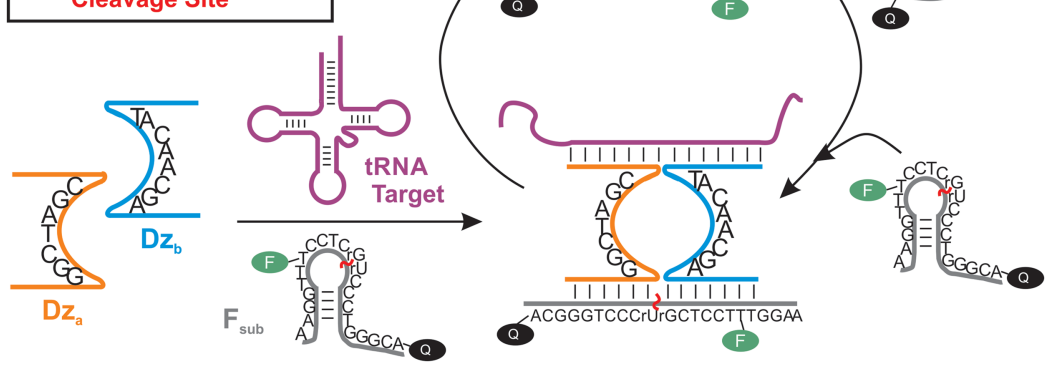

FIGURE 2. Design and catalytic cycle for signal generation by a split deoxyribozyme (sDz) probe based on the 10-23 deoxyribozyme (Dz). (A) Catalytic core of the 10-23 Dz and schematic representation of the Dz-substrate complex. $(B)$ In the sDz probe, the sequence of the 10-23 catalytic core is split between two strands, $D z_{a}$ and $D z_{b}$, which also contains fragments complementary to a tRNA target and fluorogenic substrate $\left(F_{\text {sub }}\right)$. The core is assembled only in the presence of the target, which brings $D z_{a}$ and $D z_{b}$ into proximity. Active $D z$ catalyzes cleav-

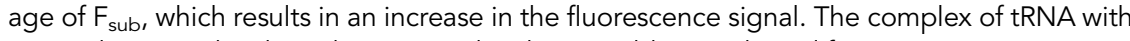
$\mathrm{D} z_{\mathrm{a}}$ and $\mathrm{Dz} \mathrm{z}_{\mathrm{b}}$ can bind another $\mathrm{F}_{\text {sub }}$ molecule to enable signal amplification. 
formation of the catalytic core, when each target simultaneously binds both sDz strands (Fig. 2B), and respective cleavage of the fluorogenic substrate result in decreased affinity of the sDz strands to the substrate fragments and, thereby, separation of the fluorophore from the quencher causing an increase in fluorescence in a target-dependent manner. Even though the substrate requires conjugation with two dyes, similarly to MBP, it does not interact with the target directly and so is universal for the sDz probes interrogating different target sequences. Moreover, the fluorogenic substrate does not directly interact with the target, so the background and the target-triggered signal can be independently fine-tuned by varying the length of the $F_{\text {sub- }}$ and target-binding regions of sDz, respectively.

\section{RESULTS AND DISCUSSION}

\section{Design and optimization of the $\mathrm{sDz}$ probes}

We designed split $\mathrm{Dz}(\mathrm{sDz})$ probes targeting cytosolic tRNA $^{\text {Phe }}$ from Saccharomyces cerevisiae as a model tRNA target. The secondary structure and targeted regions of tRNA $^{\text {Phe }}$ are shown in Figure 3 . The probe interrogated the 3 '-terminal fragment of tRNA containing the variable loop, since this region is the least conserved among different tRNA sequences (Goodenbour and Pan 2006). The target-binding regions for the $\mathrm{sDz}$ probe were designed to

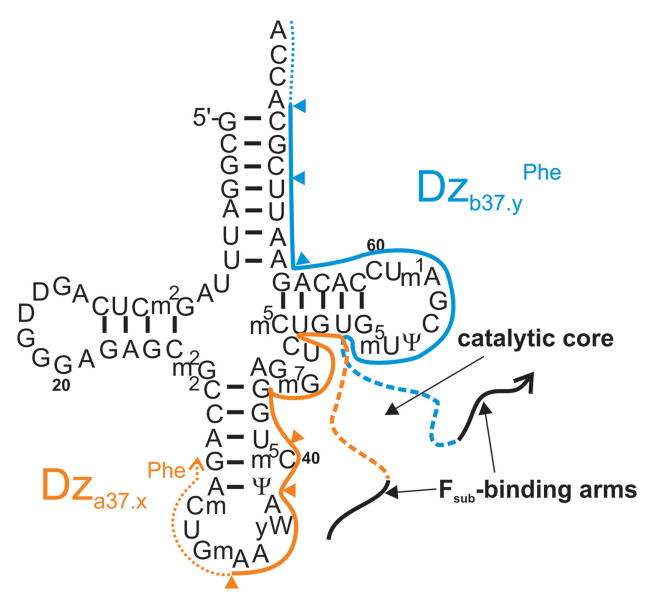

FIGURE 3. Secondary structure of $S$. cerevisiae tRNA ${ }^{\text {Phe }}$ (Serebrov et al. 1998) and its regions interrogated by the sDz probes. A set of $\mathrm{sDz}$ probes containing strands $\mathrm{Dz}_{\mathrm{a} 37 .}{ }^{\text {Phe }}$ and $\mathrm{Dz}_{\mathrm{b} 37 .}$ Phe, where $x$ and $y$ stand for the number of nucleotides in their tRNA ${ }^{\text {Phe }}$-binding regions (Supplemental Table S1), are schematically shown in orange and blue, respectively. The solid lines indicate the target-binding regions of strands $\mathrm{Dz}_{\mathrm{a} 37.17}{ }^{\text {Phe }}$ and $\mathrm{Dz} \mathrm{z}_{\mathrm{b} 37.21}{ }^{\text {Phe }}$. Elongation of the fragments to make $D z_{a 37.22}{ }^{\text {Phe }}$ and $D z_{b 37.25}{ }^{\text {Phe }}$. The positions of strand shortening to make other $\mathrm{Dz}$ and $\mathrm{Dz}_{\mathrm{b}}$ strands are indicated by triangles. The

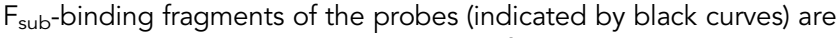
designed to work at $37^{\circ} \mathrm{C}$. The $3^{\prime}$-ends of the target and probes are indicated with arrows. For the identity of the modified bases in yeast tRNA $^{\text {Phe }}$, see Supplemental Table S2. interact with the tRNA target via Watson-Crick base pairs, whenever possible (Supplemental Table S1). For the modified bases, the base pairs were chosen to minimize disruptions to the helix of the target-probe complex if a logical pairing was not evident. For example, S. cerevisiae tRNA ${ }^{\text {Phe }}$ contains a wybutosine (yW) base in its anticodon loop, which does not pair well with any of the natural nitrogenous bases. In the probe-target complex, a T was placed opposite to $\mathrm{yW}$. The target fragment interacting with $\mathrm{Dz}_{\mathrm{a}}$ was located immediately next to the $\mathrm{Dz}_{\mathrm{b}}$-binding fragment. In the initial probe optimization stage, though, a synthetic DNA analog of tRNA ${ }^{\text {Phe }}$ (DNA ${ }^{\text {Phe }}$ ) was utilized. The bases chosen to replace the modified bases in this analog can be seen in Supplemental Table S2.

The catalytic core of the 10-23 Dz was used in the probe design, since it is the most efficient RNA-cleaving Dz currently available (Santoro and Joyce 1997), and the Dz catalytic efficiency correlates with the ability of the Dz-based probes to detect the lowest target concentration (Gerasimova et al. 2010). The core splitting and the fluorogenic substrate sequence have been previously reported to operate at $55^{\circ} \mathrm{C}$ (Mokany et al. 2010; Gerasimova et al. 2015), which would make it easier to unwind long and highly structured natural RNA (e.g., bacterial rRNA). At ambient temperatures (e.g., $37^{\circ} \mathrm{C}$ ), formation of the probe-RNA complex would not be as favored. Indeed, when we tested $\mathrm{sDz} 55^{\text {Phe }}$ containing $\mathrm{Dz}_{\mathrm{a} 55}{ }^{\text {Phe }}$ and $\mathrm{D} \mathrm{z}_{\mathrm{b} 55}{ }^{\text {Phe }}$ with the $\mathrm{F}_{\text {sub-binding regions previ- }}$ ously optimized for $55^{\circ} \mathrm{C}$, high background and little dependence of the signal on the DNA ${ }^{\text {Phe }}$ concentration was observed (Supplemental Fig. S1). High background fluorescence likely resulted from the target-independent formation of the catalytic core upon binding of $D z_{a}$ and

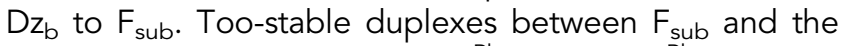
complementary regions of $\mathrm{Dz}_{\mathrm{a} 55}{ }^{\text {Phe }}$ and $\mathrm{Dz}_{\mathrm{b} 55}{ }^{\text {Phe }}$ (predicted $T_{m}$ values were $50.3^{\circ} \mathrm{C}$ and $42.9^{\circ} \mathrm{C}$, respectively) could help maintain stable association of the probe strands with the substrate at the assay temperature $\left(37^{\circ} \mathrm{C}\right)$ regardless of the target's presence. Moreover, the products of $F_{\text {sub }}$ cleavage would remain associated with the probe, thus preventing binding to new $F_{\text {sub }}$ molecules, which can explain the lack of target-induced signal increase. To enable the probe's operation at $37^{\circ} \mathrm{C}$, the $\mathrm{F}_{\text {sub-binding } \mathrm{sDz} \text { re- }}$ gions were shortened to design probes $\mathrm{sDz} 37^{\text {Phe }}$. The $T_{m}$ values of the $F_{\text {sub-binding fragments of the new }}$ strands $\left(\sim 25^{\circ} \mathrm{C}\right)$ were below the operating temperature to ensure $F_{\text {sub }}$ turnover and that the $F_{\text {sub }}$ can only be bound when $\mathrm{Dz}_{\mathrm{a}}$ and $\mathrm{Dz} \mathrm{z}_{\mathrm{b}}$ are brought into proximity by the target. This indeed helped to mitigate high background and achieve target concentration-dependent increase of the signal (Supplemental Fig. S2). The signal increased with increasing concentration of probe strands without compromising the background, so all subsequent experiments used $200 \mathrm{nM} \mathrm{Dz_{a }} / \mathrm{Dz}_{\mathrm{b}}$, unless otherwise noted. The high strand concentration favored formation of 
the probe-target complex, which enable RNA detection at low concentration.

We further optimized the performance of $\mathrm{sDz} 37^{\text {Phe }}$ by varying the lengths of the tRNA-binding fragments of $D z_{a}$ and $D z_{b}$. The melting temperature $\left(T_{m}\right)$ for the fragments interacting with their complementary sequences ranged from $\sim 51^{\circ} \mathrm{C}$ to $71^{\circ} \mathrm{C}$ (Supplemental Table S1). The values significantly above the hybridization temperature $\left(37^{\circ} \mathrm{C}\right)$ were needed to efficiently interrogate the tRNA structure, which is known to have high thermodynamic stability (Liu and Tan 1995). It should be noted that all sDz37 ${ }^{\text {Phe }}$ variants shared the same $F_{\text {sub-binding }}$ fragments, so the background signal in the absence of the target remained the same. At the same time, for most of the probes tested with yeast tRNA ${ }^{\text {Phe }}$, the signalto-background ratio $(S / B)$ increased with the length of the target-binding fragments of the sDz strands (Supplemental Fig. S3A). For the detection of 25 nM tRNA ${ }^{\text {Phe }}$ with an S/B of at least 3 , the target-binding regions of $\mathrm{Dz}$ a and $\mathrm{D} z_{\mathrm{b}}$ with a $T_{\mathrm{m}}$ of $\sim 60^{\circ} \mathrm{C}$ or above was required. Therefore, we chose the $\mathrm{sDz} 37^{\text {Phe }}$ probe consisting of strands $\mathrm{Dz} \mathrm{z}_{\mathrm{a} 37.1^{\text {Phe }}}$ and $\mathrm{Dz} \mathrm{z}_{\mathrm{b} 37.2^{\text {Phe }}}$ for subsequent characterization, unless indicated otherwise. As expected, for DNA $^{\text {Phe }}$ lacking a stable tertiary structure of tRNA and modified bases, the $\mathrm{sDz} 37^{\text {Phe }}$ probes with lower $T_{\mathrm{m}}$ for the target-binding regions were also efficient (Supplemental Fig. S3B).

\section{Detection of tRNA ${ }^{\text {Phe }}$ by $\mathrm{sDz} 37^{\text {Phe }}$}

We further characterized $\mathrm{sDz} 37^{\text {Phe }}$ containing $\mathrm{Dz} \mathrm{z}_{\mathrm{a} 37.1^{\text {Phe }}}$ and $D z_{b 37.2}{ }^{\text {Phe }}$ in terms of the time-dependence of signal generation, linear dynamic range, and limit of detection (LOD) of yeast tRNA ${ }^{\text {Phe }}$. The target-dependent sDz signal increases over time (Fig. 4A; Supplemental Fig. S4A), which is consistent with the signal-generation mechanism
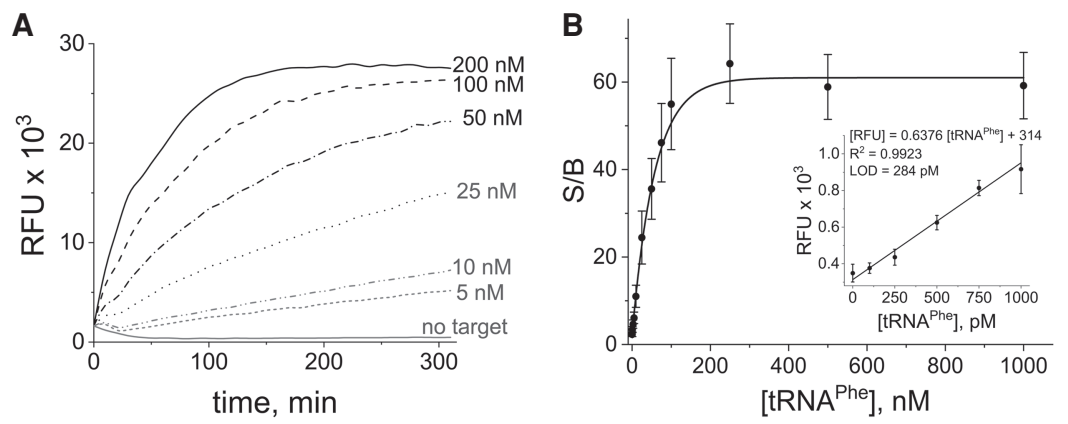

FIGURE 4. Response of $s \mathrm{Dz} 37^{\text {Phe }}$ to $t R N A^{\text {Phe }}$. (A) Time-dependence for the signal of the probe containing $D z_{\mathrm{a} 37.22}{ }^{\text {Phe }}$ and $D z_{\mathrm{b} 37.21}{ }^{\text {Phe }}$ at different concentrations of tRNA ${ }^{\text {Phe }}$ (5-200 nM). (B) Response of the probe containing $\mathrm{Dz}_{\mathrm{a} 37.22}{ }^{\text {Phe }}$ and $\mathrm{Dz}_{\mathrm{b} 37.21}{ }^{\text {Phe }}$ to different concentrations of tRNA $^{\text {Phe }}(0.1$ to $1000 \mathrm{nM})$ with a hyperbolic fit. (Inset) Dependence of the fluorescent response on tRNA ${ }^{\text {Phe }}$ concentration in the low range (0-1 nM) for calculation of the limit of detection. Data is the average of three independent experiments for 70 -min incubation at $37^{\circ} \mathrm{C}$, with error bars representing one standard deviation. of the sDz probe relying on the $F_{\text {sub }}$ cleavage catalyzed by the deoxyribozyme core (Fig. 2B). The background remained at the same level for up to $5 \mathrm{~h}$ (longer time points were not tested). Concentration of the catalytically active $\mathrm{sDz}$ is limited by the target concentration, since the deoxyribozyme core can be formed only when both $\mathrm{Dz}_{\mathrm{a}}$ and $D z_{b}$ are stoichiometrically bound at the adjacent fragments of the target molecule. Therefore, for the signal at low tRNA concentration (less than that of $F_{\text {sub }}$ ) to reach the same fluorescence intensity as exhibited at high concentration of target (equal to that of $F_{\text {sub }}$ ), multiple rounds of sDz-catalyzed $F_{\text {sub }}$ cleavage are required. The calculated number of turnovers for the substrate cleavage within 70 min by $\mathrm{sDz} 37^{\text {Phe }}$ at different concentrations of tRNA ${ }^{\text {Phe }}$ are listed in Supplemental Table S3. It should be noted that these calculations were performed under the assumption that each target molecule forms the Dz core. The observed catalytic rate constants under multiple turnover conditions ( $5 \mathrm{nM}$ target) were calculated to be $0.05 \pm$ $0.01 \mathrm{~min}^{-1}$ and $0.6 \pm 0.1 \mathrm{~min}^{-1}$ for tRNA ${ }^{\text {Phe }}$ and DNA ${ }^{\text {Phe }}$, respectively (Supplemental Fig. S4B). The 10-fold difference in the case of tRNA versus DNA target can be explained by the presence of modified bases that stabilize the tertiary structure. For the DNA target lacking tertiary interactions but exhibiting stable secondary structure, the catalytic rate was only three- to fivefold lower than that of the monolith 10-23 Dz under similar conditions as used in this paper (Santoro and Joyce 1998).

The signal increased linearly with the tRNA concentration up to 150 nM (Fig. 4B; Supplemental Fig. S5A). The large linear dynamic range can be helpful in quantifying tRNA targets in samples, if needed. This has a potential application in clinical molecular diagnostics, since changes in levels of tRNA or tRNA-derived fragments have been reported to be associated with various diseases including cancer (Abbott et al. 2014; Lant et al. 2019). As expected, because of the higher thermal stability of tRNA in comparison to that of its correspondent DNA analog, as well as the presence of modified bases in the tRNA target, a narrower linear dynamic range (0-5 nM) was observed in the presence of DNA ${ }^{\text {Phe }}$ (Supplemental Fig. S5A). Indeed, a $T_{\mathrm{m}}$ value for the folded $\mathrm{DNA}^{\mathrm{Phe}}$ conformation at $150 \mathrm{mM} \mathrm{Mg}^{2+}$ is $\sim 60^{\circ} \mathrm{C}$ (as predicted by the melt profile of NUPACK software), while the $T_{m}$ of tRNA (sequence not specified) under the same condition has been previously reported to be $\sim 72^{\circ} \mathrm{C}$ $\left(70.4^{\circ} \mathrm{C}\right.$ and $78.0^{\circ} \mathrm{C}$ for $100 \mathrm{mM}$ and $300 \mathrm{mM} \mathrm{Mg}^{2+}$, respectively), assuming a linear correlation (Stein and Crothers 1976). 
For the LOD calculation, a 70-min assay time was chosen as a compromise between a short assay time and high S/B values. The LOD calculated according to the $3 \sigma$ rule (Skoog et al. 2018) was 16 and 284 pM for synthetic $\mathrm{DNA}^{\text {Phe }}$ target and natural tRNA ${ }^{\text {Phe }}$, respectively (Fig. 4B, inset; Supplemental Fig. S5B). By increasing the assay's time and/or temperature, it is possible to further improve the LOD. The 70-min LOD for tRNA ${ }^{\text {Phe }}$ is about two orders of magnitude lower than the previously reported LOD determined for the in-stem MBP targeting a similar region of the unmodified tRNA transcript (Miyoshi et al. 2019).

It is known that unmodified RNA transcripts can acquire secondary and tertiary structures that closely resemble that of mature tRNA (Byrne et al. 2010), but some base modifications can affect the thermal stability of the fully folded RNA molecules (Serebrov et al. 1998; Helm 2006). Therefore, to directly compare the two probes, we designed a MBP Phe probe (Supplemental Table S1) targeting the same region of yeast $\mathrm{TRNA}^{\text {Phe }}$ as the $\mathrm{sDz}$ probes described here. The MBP ${ }^{\text {Phe }}$ demonstrated the LOD of 15.2 $\mathrm{nM}$ while interrogating the $\mathrm{DNA}^{\mathrm{Phe}}$ target, which is within an order of magnitude from the LOD values reported for MBPs ( $\approx 1 \mathrm{nM}$ ) (Kolpashchikov 2012). The slightly higher higher LOD observed for DNA ${ }^{\text {Phe }}$ was expected because of the highly stable secondary structure of the target. At the same time, there was no statistically significant response of MBP Phe to tRNA ${ }^{\text {Phe }}$ at up to $200 \mathrm{nM}$ target concentration (Supplemental Fig. S6). Indeed, previous works required tRNA concentrations in the high $\mathrm{nM}$ to $\mu \mathrm{M}$ range to trigger the target dependent response ( $\mathrm{Li}$ et al. 2017; Miyoshi et al 2019).

\section{Effect of 1-methyladenosine in tRNA ${ }^{\text {Phe }}$}

The primary structure of yeast tRNA ${ }^{\text {Phe }}$ contains 1-methyladenosine $\left(m^{1} A\right)$ at position 58 (Fig. 3). This modification is conserved in tRNA from different organisms and is known to be important for maintaining tRNA tertiary structure (Anderson and Droogmans 2005). Presence of the methyl group at N1 of adenosine has been reported to cause switching from the canonical Watson-Crick base-pairing to $\mathrm{T} \cdot \mathrm{m}^{1} \mathrm{~A}$ Hoogsteen base pair (Fig. 5A; Yang et al. 2008), which reduces the thermodynamic stability of the B-DNA double helix (Yang and Lam 2009). At the same time, formation of the A-U Hoogsteen base pair is strongly disfavored in A-RNA duplexes (Zhou et al. 2016). To shed light on interactions between $\mathrm{m}^{1} \mathrm{~A} 58$ of tRNA ${ }^{\text {Phe }}$ and a DNA-based hybridization probe $\mathrm{sDz} 37^{\text {Phe }}$, we designed a set of strands $D z_{b 37.21} N^{\text {Phe }}$ that differed in the nucleotide (N) to pair with $m^{1} A 58$ (Supplemental Table S1). We then compared the response of four $\mathrm{sDz} 37^{\text {Phe }}$ variants (each containing the same $\mathrm{Dz}_{\mathrm{a} 37.17}$ Phe and different $D z_{b 37.21 N^{P h}}$ ) to the same concentration of tRNA ${ }^{\text {Phe }}$. While all four probes efficiently interrogated the target with high $S / B$, clear preference of the $m^{1} A$-containing tRNA frag-
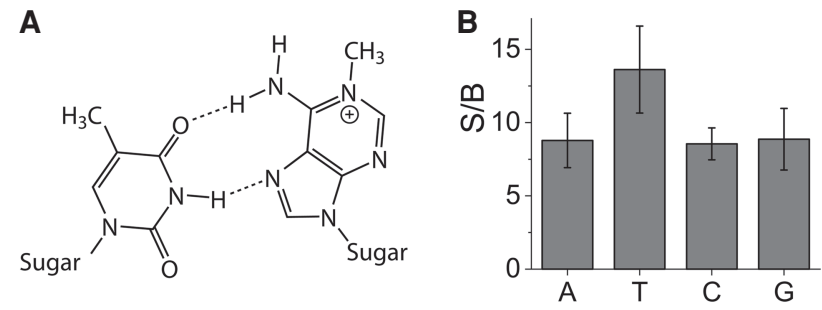

FIGURE 5. Response of the $s D z^{\text {Phe }}$ probes differing in the nucleotide pairing with $\mathrm{m}^{1} \mathrm{~A} 58$ of $\mathrm{tRNA} \mathrm{P}^{\mathrm{Phe}}$. (A) 1-Methyladenosine can form a Hoogsteen base pair with thymidine (Yang et al. 2008). (B) Four probes containing $\mathrm{Dz}_{\mathrm{a} 37.17}{ }^{\text {Phe }}$ and one of the four $\mathrm{Dz} \mathrm{z}_{\mathrm{b} 37.21 \mathrm{~N}}{ }^{\text {Phe }}$ ( $\mathrm{N}$ corresponds to the nucleotide pairing with $\mathrm{m}^{1} \mathrm{~A}$ and is indicated below the correspondent bars of the graph) were incubated with $50 \mathrm{nM}$ tRNA $^{\text {Phe }}$ for $3 \mathrm{~h}$. The data of five independent experiments were averaged, with the error bars corresponding to one standard deviation.

ment to interact with the T-containing $\mathrm{sDz} 37^{\text {Phe }}$ was observed (Fig. 5B; $P=0.05-0.09$ ). These data deviate from the stability trend $T \cdot m^{1} A \approx G \cdot m^{1} A<A \cdot m^{1} A<C \cdot m^{1} A$ observed for DNA duplexes (Yang and Lam 2009). This discrepancy may reflect different conformations of basepairing in B-DNA and tRNA-DNA hybrids. High signal observed for all the sDz37 $7^{\text {Phe }}$ probes studied can be attributed to the long target-binding region of $\mathrm{Dz}_{\mathrm{b} 37.21 \mathrm{~N}}{ }^{\text {Phe }}$, which can tolerate imperfections in tRNA-probe base-pairing.

\section{Generality of the design and selectivity of the sDz probe}

To demonstrate that the same design principles can be applied to a sDz specific to another native structured RNA target, probe sDz37 ${ }^{18 S}$ interrogating a $5^{\prime}$-terminal fragment (nt 15-51) of S. cerevisiae 18S rRNA was designed (Supplemental Fig. S7). The probe consisted of $\mathrm{Dz}_{\mathrm{a} 37}{ }^{18 \mathrm{~S}}$ and $\mathrm{Dz}_{\mathrm{b} 37}{ }^{18 \mathrm{~S}}$ (Supplemental Table S1), which shared the sequences of the $\mathrm{Dz}$ core and $\mathrm{F}_{\text {sub-binding fragments }}$ with the corresponding strands of $s D z 37^{\text {Phe }}$. Figure $5 \mathrm{~A}$ shows response of $\mathrm{sDz} 37^{18 \mathrm{~S}}$ or $\mathrm{sDz} 37^{\text {Phe }}$ to the total RNA preparation from $S$. cerevisiae and to purified tRNA ${ }^{\text {Phe, }}$ $18 \mathrm{~S}$ rRNA, or $26 \mathrm{~S}$ rRNA. Each probe showed appreciable response only in the presence of its cognate target or the target-containing total RNA sample.

To demonstrate the selectivity of target recognition for different tRNA species, the probe $\mathrm{sDz} 37^{\text {Ser }}$ targeting another tRNA from S. cerevisiae - tRNA ${ }^{\text {Ser}}$ (UGA) (Supplemental Table S1)—was designed and initially characterized with the DNA ${ }^{\text {Ser }}$ analyte, since isolated tRNA ${ }^{\text {Ser }}$ is not commercially available. The designed $\mathrm{sDz} 37^{\text {Ser }}$ probe demonstrated an LOD of $29.7 \mathrm{pM}$ and a linear dynamic range of 10-500 pM DNA ${ }^{\text {Ser }}$ (Supplemental Fig. S8). Then, the response of both $\mathrm{sDz} 37^{\mathrm{Ser}}$ and $\mathrm{sDz} 37^{\text {Phe }}$ to isolated tRNA ${ }^{\text {Phe }}$ or to a total transfer RNA sample obtained from $S$. cerevisiae was analyzed (Fig. 6B). An S/B of $5.3 \pm$ 0.8 was observed for $\mathrm{sDz} 37^{\text {Phe }}$ in the presence of tRNA ${ }^{\text {Phe, }}$, 

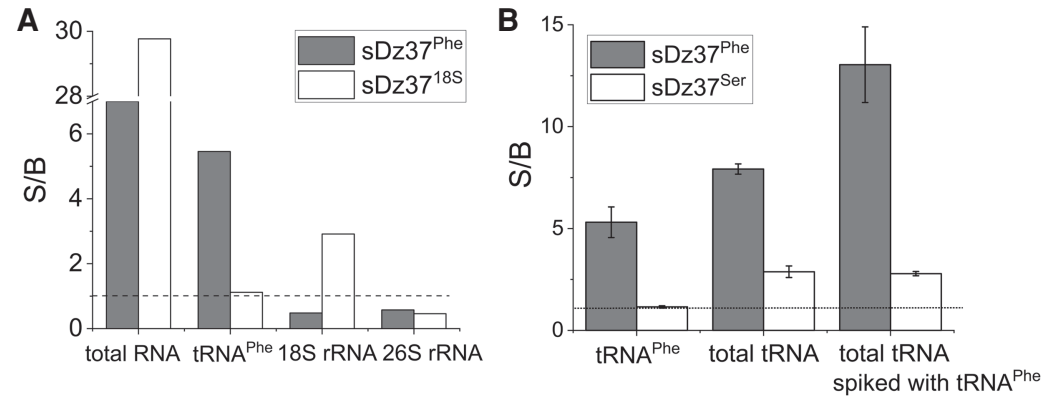

FIGURE 6. Selective target recognition by $s D z 37^{18 \mathrm{~S}}, \mathrm{sDz} 37^{\mathrm{Phe}}$, and $\mathrm{sDz} 37^{\mathrm{Ser}}$. (A) Response of $\mathrm{sDz} 37^{\text {Phe }}$ (gray bars) and sDz37 ${ }^{18 \mathrm{~S}}$ (white bars) to total RNA from S. cerevisiae $(20.5 \mathrm{ng} / \mu \mathrm{L}$ ), or isolated yeast tRNA ${ }^{\text {Phe }}(50 \mathrm{nM}), 18 \mathrm{~S}$ rRNA $(18 \mathrm{nM})$, or $26 \mathrm{~S}$ rRNA $(26 \mathrm{nM})$. The probe $s \mathrm{~s} 37^{\text {Phe }}$ contained strands $\mathrm{Dz}_{\mathrm{a} 37.17^{\text {Phe }}}$ and $\mathrm{Dz} \mathrm{z}_{\mathrm{b} 37.21}{ }^{\text {Phe }}$. Higher $\mathrm{S} / \mathrm{B}$ for $\mathrm{sDz} 37^{18 \mathrm{~S}}$ in comparison to $\mathrm{sDz} 37^{18 \mathrm{~S}}$ reflects higher abundance of the probe's cognate target in the total RNA sample. (B) Response of sDz37 ${ }^{\text {Phe }}$ (gray bars) and sDz37 ${ }^{\text {Ser }}$ (white bars) to total transfer RNA from S. cerevisiae $(100 \mathrm{ng} / \mu \mathrm{L})$ with or without isolated tRNA ${ }^{\text {Phe }}(50 \mathrm{nM})$ spiked, or to the isolated yeast $\operatorname{tRNA}^{\text {Phe }}(50 \mathrm{nM})$, as indicated below the bars. A threshold of $S / B=1$ is shown with a dotted line.

while $\mathrm{sDz} 37^{\text {Phe }}$ responded to the same tRNA ${ }^{\text {Phe }}$ concentration with an $S / B$ of $1.15 \pm 0.06$, which is almost at the background level $(S / B=1$, denoted with a dotted threshold line in Fig. 6B). At the same time, the total tRNA sample triggered high signal for both probes. The higher response observed for $\mathrm{sDz} 37^{\text {Phe }}$ relative to $\mathrm{sDz} 37^{\text {Ser }}$ can result from higher abundance of the tRNA ${ }^{\text {Phe }}$ in the total tRNA preparation, as well as better $\mathrm{sDz} 37^{\text {Phe }}$ sensitivity (as can be seen by comparing the LOD values obtained for the cognate synthetic DNA targets). However, when the same amount of total tRNA was spiked with $50 \mathrm{nM}$ tRNA ${ }^{\text {Phe }}$, a statistically significant signal increase was observed for $\mathrm{sDz} 37^{\text {Phe }}$ but not for $\mathrm{sDz} 37^{\text {Ser }}$ (Fig. 6B). Indeed, for the data sets with $\mathrm{sDz} 37^{\text {Phe }}$ and sDz37 ${ }^{\text {Ser }}, P=0.009$ and $P=0.6$, respectively, sDz37 has shown to differentiate between tRNA targets. Moreover, both $\mathrm{sDz} 37^{\text {Phe }}$ and $\mathrm{sDz} 37^{\text {Ser }}$ demonstrated excellent selectivity of DNA target recognition (Supplemental Fig. S9). Indeed, each probe exhibited high signal in response to its specific DNA target in a concentration-dependent manner, even at high concentration of the nonspecific target, no signal above the background was observed. If taking into account that the sDz probes interrogate their cognate DNA targets more efficiently than tRNA (Supplemental Fig. S5A), selective DNA target recognition ensures high selectivity of the probe with respect to tRNA. Therefore, high affinity of the $\mathrm{sDz}$ probe to the target does not compromise the probe's selectivity, unlike that of stateof-the-art hybridization probes (Demidov and Frank-Kamenetskii 2004).

In the analysis of tRNA sequences, some applications may require a hybridization probe to discriminate against single mismatches in the tRNA structure. Indeed, single mutations in mitochondrial and cytosolic tRNA have been linked to pathogenesis (Florentz and Sissler 2001; Abbott et al. 2014; Huang et al. 2018). To demonstrate such dis- criminatory capabilities of sDz37, we used the probe containing one of the strands with a single nucleotide substitution at the position interacting with C48 of tRNA ${ }^{\text {Phe }}$ (strand $\mathrm{Dz}_{\mathrm{a} 37.13 \mathrm{C}^{\text {Phe}}}$; Supplemental Table S1). This probe responded to tRNA ${ }^{\text {Phe }}$ with an S/B of only $1.4 \pm 0.2$, while the matched $\mathrm{sDz} 37^{\text {Phe }}$ probe containing targetcomplementary strand $\mathrm{Dz}_{\mathrm{a} 37.13^{\text {Phe }}}$ exhibited an S/B of $5.4 \pm 0.7$ (Fig. 7). It should be noted that some optimization of the probe's design was required for the signal of the mismatch probe to be close to the background level. Indeed, the used probe contained the mismatched strand with a short (13-nt) target-binding fragment. Such optimization required lower monetary investment than that for MBP since this strand is a relatively short inexpensive unmodified DNA oligomer.

\section{Detection of tRNA in cellular lysates}

Following characterization of the sDz37 probes targeting two different tRNA and an rRNA from S. cerevisiae, we explored the use of the probes for a practical laboratory application: detection of tRNA directly from cellular lysates. Ideally, little to no workup of the sample should be needed to obtain a quantitative measure of a particular tRNA. Here, we demonstrated that the probes can work with minimally processed yeast cells that underwent lysis by boiling. For this purpose, S. cerevisiae cells were grown to the beginning of stationary phase, and the cell culture was then diluted with the liquid media to prepare samples containing $10 \%-100 \%$ original cell culture. The samples were then tested with both $\mathrm{sDz} 37^{\text {Phe }}$ and sDz3 $7^{\text {Ser }}$ probes

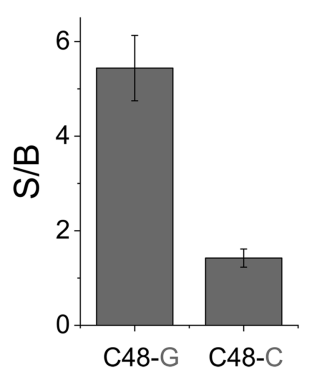

FIGURE 7. Ability of sDz37 to differentiate single base mispairing with tRNA ${ }^{\text {Phe }}$. tRNA $^{\text {Phe }}$ triggered response of two variants of $\mathrm{sDz} 37^{\text {Phe }}$ containing the same $\mathrm{Dz}_{\mathrm{b} 37.21}$ Phe strand and either $\mathrm{Dz}_{\mathrm{a} 37.13}{ }^{\text {Phe }}$ or $\mathrm{Dz} \mathrm{z}_{\mathrm{a} 37.13 \mathrm{C}^{\text {Phe }}}$ strand (Supplemental Table S1), which contained either $\mathrm{G}$ or $\mathrm{C}$ residue, respectively, in the position interacting with C48 of tRNA ${ }^{\text {Phe }}$ (indicated as C48-G or C48-C below the bars). 
(Fig. 8). It can be seen that the signal for both probes increased with the amount of cells used in the assay (Fig. 8A).

We then confirmed the selectivity of the sDz probes by spiking yeast cells with different concentrations of tRNA $^{\text {Phe }}$. In the case of $\mathrm{sDz} 37^{\text {Phe }}$, the signal triggered by $10 \%$ cell lysate was similar to that in the presence of 10 nM tRNA ${ }^{\text {Phe }}$ in the assay buffer (Fig. 8B, gray bars). Addition of $10 \mathrm{nM}$ tRNA ${ }^{\text {Phe }}$ to the cell lysate sample roughly doubled the signal. An increase in the spiked tRNA ${ }^{\text {Phe }}$ concentration resulted in correspondent increase of the $\mathrm{sDz} 37^{\text {Phe }}$ signal. At the same time, the signal of the $\mathrm{sDz} 37^{\text {Ser }}$ triggered by $10 \%$ cell lysate was not affected much by the addition of increased concentrations of tRNA $^{\text {Phe }}$ (Fig. 8B, compare last four bar sets). Therefore, the high selectivity of the sDz probes is not compromised by the presence of other components of such a complex matrix as cellular lysates. We also demonstrated the feasibility of sDz probes for tRNA level monitoring during cell growth (Supplemental Fig. S10). Thus, the sDz assay can be used to selectively monitor the levels of specific RNA targets in the presence of other cellular components.

\section{Conclusions}

Here, we designed a multicomponent deoxyribozymebased hybridization probe that can efficiently interrogate such highly structured and modified RNA targets as eukaryotic tRNA and rRNA. We demonstrated the ability of the probe to detect low levels of tRNA (down to the subnanomolar range) and its high selectivity in recognition of its specific tRNA target even in a complex medium, such as cell lysate. Moreover, the ability of the multicomponent probe to differentiate between single mispairing in the tRNA-probe complexes was shown, which can be used in the analysis of disease-associated tRNA mutations. The probe can be used for monitoring specific RNA molecules in cells in biomedical research and may find application in molecular diagnostics.
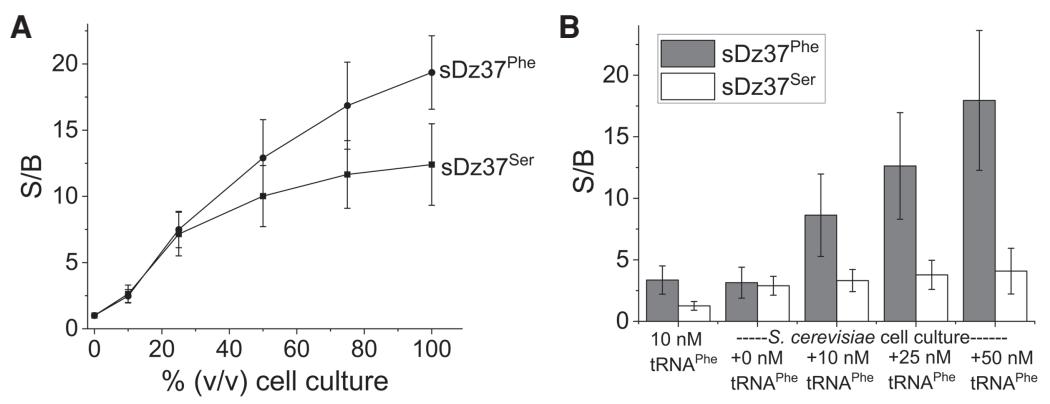

FIGURE 8. Response of the sDz probes to $S$. cerevisiae cell lysate. (A) Response of sDz37Phe (circles) and sDz37 $7^{\text {Ser }}$ (squares) to different cell culture dilutions. (B) Response sDz37 ${ }^{\text {Phe }}$ (gray bars) and sDz $37^{\text {Ser }}$ (white bars) to the $10 \%$ cell culture dilution spiked with different concentrations of yeast tRNA ${ }^{\text {Phe }}$. The data is the average of three independent experiments, with error bars as one standard deviation.

\section{MATERIALS AND METHODS}

\section{Materials}

All chemicals were purchased from Fisher Scientific. Oligonucleotides were purchased from Integrated DNA Technologies. Fluorogenic reporter substrate $\left(F_{\text {sub }}\right)$ was purchased from TriLink BioTechnologies. Phenylalanine-specific tRNA from brewer's yeast, and Saccharomyces cerevisiae yeast cells were obtained from Millipore Sigma.

\section{Nucleic acid preparation}

Oligonucleotides and yeast tRNA ${ }^{\text {Phe }}$ were dissolved in RNase free water, and their stock concentrations were determined based on their absorbance at $260 \mathrm{~nm}$ using extinction coefficients estimated by OligoAnalyzer tool (Integrated DNA Technologies).

\section{Probe design}

tRNA sequences (Supplemental Table S1) were obtained from the tRNA database (Universitat Leipzig, http://trnadb.bioinf.unileipzig.de/). The probes were designed using minimal free energy values for target-binding regions of the probes and probe-target complexes predicted with the NUPACK software (www .nupack.org). Initial probe design was done using a DNA sequence analog of the tRNA target. The canonical bases chosen to replace the modified bases of tRNA can be seen in Supplemental Table S2. Melting temperatures of the probe's fragments bond to their complementary sequences were predicted by the OligoAnalyzer tool (https://www.idtdna.com/calc/ analyzer) under the optimized assay conditions.

\section{Fluorescent assay with sDz probes}

To a mixture containing $D z_{a} / D z_{b}(200 n M)$ and $F_{\text {sub }}(200 \mathrm{nM})$ in an assay buffer (50 mM HEPES (pH 8.0), $150 \mathrm{mM} \mathrm{MgCl}, 20$ $\mathrm{mM} \mathrm{KCl}, 120 \mathrm{mM} \mathrm{NaCl}, 1 \% \mathrm{v} / \mathrm{v} \mathrm{DMSO}$ ), a target at varying concentrations (1-200 nM) was added, and the reaction mixture was incubated at $37^{\circ} \mathrm{C}$. For the experiments with yeast cells, a sample of lysed cells was mixed with the equal volume of the assay buffer $\times 2$ containing $D z_{a} / D z_{b} / F_{\text {sub }}$ (each at $200 \mathrm{nM}$ ) followed by incubation at $37^{\circ} \mathrm{C}$. Fluorescence measurements were taken using a Tecan M200Pro plate reader, and excitation at $475 \mathrm{~nm}$ (9-nm slit) and emission at $525 \mathrm{~nm}$ (20-nm slit). The data analysis was performed with Excel. The response of the probe was shown either in relative fluorescent units (RFU) or as signal-to-background ratio (S/B) calculated by dividing the RFU values for the probe in the presence of the target by that of the background (no-target blank). Limit of detection (LOD) was determined by dividing three standard deviations of the average blank by the slope of the 
best fit line of the RFU values plotted as a function of target concentration.

\section{Catalytic turnover}

The samples containing $\mathrm{F}_{\text {sub }}(200 \mathrm{nM})$, strands $\mathrm{Dz}_{\mathrm{a} 37.1}$ Phe and $\mathrm{Dz}_{\mathrm{b} 37.2^{\text {Phe }}}$ (200 nM each), and either tRNA ${ }^{\text {Phe }}$ or DNA ${ }^{\text {Phe }}$ (5-200 $\mathrm{nM}$ ) were incubated in the assay buffer at $37^{\circ} \mathrm{C}$ for $70 \mathrm{~min}$. Fluorescence measurements were taken every 10 min using a Tecan M200Pro plate reader, and excitation at $475 \mathrm{~nm}$ (9-nm slit) and emission at $525 \mathrm{~nm}$ (20-nm slit). As a background, fluorescence of the sample in the absence of the target was used. The percent and concentration of the cleaved $F_{\text {sub }}$ was calculated by dividing the fluorescence intensity of the target-containing sample after subtraction of the background at each target concentration at every time point by the maximal intensity for the sample containing 200 nM target (single turnover conditions). To calculate the number of cleavage reactions, it was assumed that each target molecule triggers formation of the catalytic core by interacting with $\mathrm{Dz}$ a and $\mathrm{Dz}_{\mathrm{b}}$. The calculated concentration of the cleaved $F_{\text {sub }}$ for each target concentration was divided by the target concentration to obtain the number of cleavage rounds. The data of three experiments were analyzed independently, and the calculated numbers were averaged with an error in the form of one standard deviation. The observed rate constant for $F_{\text {sub }}$ cleavage was calculated as a slop of a linear trendline obtained by plotting the number of cleavage rounds (turnovers) for the sample containing $5 \mathrm{nM}$ target (multiple-turnover condition) as a function of time for the first $60 \mathrm{~min}$ or $40 \mathrm{~min}$ for $\mathrm{tRNA} \mathrm{Ph}^{\text {Phe }}$ and DNA ${ }^{\text {Phe }}$ targets, respectively.

\section{Yeast cell growth and lysis}

Freeze-dried yeast cells from Saccharomyces cerevisiae type II (50-150 mg) were suspended in $10 \mathrm{~mL}$ of a liquid medium (37 mM KH $2 \mathrm{PO}_{4}, 15 \mathrm{mM}\left(\mathrm{NH}_{4}\right)_{2} \mathrm{SO}_{4}, 3.3 \mathrm{mM} \mathrm{MgSO}_{4}, 28 \mathrm{mM}$ glucose, and $0.1 \% \mathrm{w} / \mathrm{v}$ yeast extract) and incubated at $37^{\circ} \mathrm{C}$ with constant shaking at $200 \mathrm{rpm}$ for $24 \mathrm{~h}$. A $1 \mathrm{~mL}$-aliquot of the cell culture was pelleted by centrifugation at 12,000 rpm for 5 min. The liquid medium was decanted, and the cell pellet was resuspended in $1.0 \mathrm{~mL}$ of a lysis buffer (50 mM HEPES-NaOH [pH 8.0], $100 \mathrm{mM} \mathrm{NaCl}, 7.7 \% \mathrm{v} / \mathrm{v}$ glycerol). Absorbance at $600 \mathrm{~nm}$ was measured prior to centrifugation and then after cell pellet resuspension in the lysis buffer. Serial dilutions of the cell suspension in the lysis buffer were performed to obtain the samples containing $100 \%, 75 \%, 50 \%, 25 \%$, and $10 \%$ of the stock cell suspension. The prepared cell samples were then lysed by heating in boiling water for 5 min (note: samples were usually frozen and thawed prior to use, this may have contributed to further lysing). The lysed samples were used directly in the fluorescent assay (above) with no further purification.

\section{Isolation of total RNA from S. cerevisiae}

Isolation of total RNA from S. cerevisiae was carried out using a one-step hot formamide extraction method reported by Pestov and colleagues (Shedlovskiy et al. 2017). Specifically, Saccharomyces cerevisiae cells were grown in the liquid medium at $30^{\circ} \mathrm{C}$ with constant shaking at $200 \mathrm{rpm}$ for $16 \mathrm{~h}$. The cells $\left(O D_{600}=1.0\right)$ were harvested by centrifugation and resuspended in $35 \mu \mathrm{L}$ of FAE solution ( $98 \%$ formamide, $10 \mathrm{mM}$ EDTA, $\mathrm{pH}$ 8.0). the suspension was heated at $70^{\circ} \mathrm{C}$ for $10 \mathrm{~min}$, briefly vortexed and centrifuged at 14,800 rpm for $2 \mathrm{~min}$. The RNA-containing supernatant was transferred into a new tube, and RNA was ethanol precipitated. The concentration of total yeast RNA was determined by measuring $\mathrm{OD}_{260}$.

\section{Purification of yeast $18 \mathrm{~S}$ and $26 \mathrm{~S}$ rRNAs}

Yeast total RNA was separated into 26S rRNA, 18S rRNA, and small RNA fractions using $0.8 \%$ agarose gel electrophoresis. The correspondent bands were excised from the gel, purified using the crash-and-soak method, and ethanol-precipitated. The RNA pellets were dissolved in RNase-free water. The isolated RNA samples were analyzed in $0.8 \%$ agarose gels, and their concentration was determined by comparing the intensities of the correspondent bands with the intensities of the bands containing RNA markers of similar size.

\section{SUPPLEMENTAL MATERIAL}

Supplemental material is available for this article.

\section{ACKNOWLEDGMENTS}

The authors are grateful to Dr. Dmitry Kolpashchikov (UCF) for critical reading of the manuscript and helpful discussions. The work was partially supported by National Institute of Allergy and Infectious Diseases grant R01Al149468.

Received January 14, 2020; accepted August 23, 2020.

\section{REFERENCES}

Abbott JA, Francklyn CS, Robey-Bond SM. 2014. Transfer RNA and human disease. Front Genet 5: 158. doi:10.3389/fgene.2014 .00158

Anderson JT, Droogmans L. 2005. Biosynthesis and function of 1methyladenosine in transfer RNA. In Fine-tuning of RNA functions by modification and editing. Topics in current genetics (ed. Grosjean H), Vol. 12, pp. 121-139. Springer, Berlin.

Brown T, Mackey K, Du T. 2004. Analysis of RNA by northern and slot blot hybridization. Curr Protoc Mol Biol 67: 4.9.1-4.9.19. doi:10 .1002/0471142727.mb0409s67

Byrne RT, Konevega AL, Rodnina MV, Antson AA. 2010. The crystal structure of unmodified tRNA Phe from Escherichia coli. Nucleic Acids Res 38: 4154-4162. doi:10.1093/nar/gkq133

Demidov V, Frank-Kamenetskii MD. 2004. Two sides of the coin: affinity and specificity of nucleic acid interactions. Trends Biochem Sci 29: 62-71. doi:10.1016/j.tibs.2003.12.007

Fang G-M, Chamiolo J, Kankowski S, Hövelmann F, Friedrich D, Löwer A, Meier JC, Seitz O. 2018. A bright FIT-PNA hybridization probe for the hybridization state specific analysis of a $\mathrm{C} \rightarrow U$ RNA edit: via FRET in a binary system. Chem Sci 9: 4794-4800. doi:10.1039/C8SC00457A

Florentz C, Sissler M. 2001. Disease-related versus polymorphic mutations in human mitochondrial tRNAs. EMBO Rep 2: 481-486. doi:10.1093/embo-reports/kve111 
Gentry RC, Childs JJ, Gevorkyan J, Gerasimova YV, Koculi E. 2015. Time course of large ribosomal subunit assembly in $E$. coli cells overexpressing a helicase inactive DbpA protein. RNA 21: 10551064. doi:10.1261/rna.055137.115

Gerasimova YV, Cornett E, Kolpashchikov DM. 2010. RNA-cleaving deoxyribozyme sensor for nucleic acid analysis: the limit of detection. Chembiochem 11: 811-817. doi:10.1002/cbic.201000006

Gerasimova YV, Yakovchuk P, Dedkova LM, Hecht SM, Kolpashchikov DM. 2015. Expedited quantification of mutant ribosomal RNA by binary deoxyribozyme (BiDz) sensors. RNA 21: 1834-1843. doi:10.1261/rna.052613.115

Goodenbour JM, Pan T. 2006. Diversity of tRNA genes in eukaryotes. Nucleic Acids Res 34: 6137-6146. doi:10.1093/nar/gkl725

Grimes J, Gerasimova YV, Kolpashchikov D M. 2010. Real-time SNP analysis in secondary-structure-folded nucleic acids. Angew Chemie Int Ed Engl 49: 8950-8953. doi:10.1002/anie.201004475

Helm M. 2006. Post-transcriptional nucleotide modification and alternative folding of RNA. Nucleic Acids Res 34: 721-733. doi:10 $.1093 / \mathrm{nar} / \mathrm{gkj} 471$

Herschlag D, Bonilla S, Bisaria N. 2018. The story of RNA folding, as told in epochs. Cold Spring Harb Perspect Biol 10: a032433. doi:10.1101/cshperspect.a032433

Huang SQ, Sun B, Xiong ZQ, Shu Y, Zhou HH, Zhang W, Xiong J, Li Q. 2018. The dysregulation of tRNAs and tRNA derivatives in cancer. J Exp Clin Cancer Res 37: 101. doi:10.1186/s13046-018-0745-z

Kim Y, Yang CJ, Tan W. 2007. Superior structure stability and selectivity of hairpin nucleic acid probes with an L-DNA stem. Nucleic Acids Res 35: 7279-7287. doi:10.1093/nar/gkm771

Kolpashchikov DM. 2007. A binary deoxyribozyme for nucleic acid analysis. Chembiochem 8: 2039-2042. doi:10.1002/cbic .200700384

Kolpashchikov DM. 2010. Binary probes for nucleic acid analysis. Chem Rev 110: 4709-4723. doi:10.1021/cr900323b

Kolpashchikov DM. 2012. An elegant biosensor molecular beacon probe: challenges and recent solutions. Scientifica (Cairo) 2012: 1-17. doi:10.6064/2012/928783

Lant JT, Berg MD, Heinemann IU, Brandl CJ, O'Donoghue P. 2019. Pathways to disease from natural variations in human cytoplasmic tRNAs. J Biol Chem 294: 5294-5308. doi:10.1074/jbc.REV118 .002982

Li J, Qi X-J, Du Y-Y, Fu H-E, Chen G-N, Yang H-H. 2012. Efficient detection of secondary structure folded nucleic acids related to Alzheimer's disease based on junction probes. Biosens Bioelectron 36: 142-146. doi:10.1016/j.bios.2012.04.003

Li J, Xu C, Shimada N, Miyoshi Y, Watanabe K, Cong W, Ohtsuki T. 2017. Detection of small, highly structured RNAs using molecular beacons. Anal Methods 9: 2971-2976. doi:10.1039/C7AY00341B

Liu Y, Tan F. 1995. Calorimetric studies of thermal denaturation of DNA and tRNAs. J Therm Anal 45: 35-38. doi:10.1007/ BF02548660

Miyoshi Y, Ohtsuki T, Kashida H, Asanuma H, Watanabe K. 2019. Instem molecular beacon targeted to a 5'-region of tRNA inclusive of the $D$ arm that detects mature tRNA with high sensitivity. PLoS One 14: e0211505. doi:10.1371/journal.pone.0211505

Mokany E, Bone SM, Young PE, Doan TB, Todd AV. 2010. MNAzymes, a versatile new class of nucleic acid enzymes that can function as biosensors and molecular switches. J Am Chem Soc 132: 1051-1059. doi:10.1021/ja9076777

Nedorezova DD, Fakhardo AF, Nemirich DV, Bryushkova EA, Kolpashchikov DM. 2019. Towards DNA nanomachines for cancer treatment: achieving selective and efficient cleavage of folded RNA. Angew Chemie Int Ed Engl 58: 4654-4658. doi:10.1002/ anie.201900829
Nguyen C, Grimes J, Gerasimova YV, Kolpashchikov DM. 2011. Molecular-beacon-based tricomponent probe for SNP analysis in folded nucleic acids. Chem Eur J 17: 13052-13058. doi:10 .1002/chem.201101987

Petersen K, Vogel U, Rockenbauer E, Nielsen KV, Kølvraa S, Bolund L, Nexø B. 2004. Short PNA molecular beacons for real-time PCR allelic discrimination of single nucleotide polymorphisms. Mol Cell Probes 18: 117-122. doi:10.1016/j.mcp.2003.10.003

Ranasinghe RT, Challand MR, Ganzinger KA, Lewis BW, Softley C, Schmied WH, Horrocks MH, Shivji N, Chin JW, Spencer J, et al. 2018. Detecting RNA base methylations in single cells by in situ hybridization. Nat Commun 9: 655. doi:10.1038/s41467-01702714-7

Rhee WJ, Santangelo PJ, Jo H, Bao G. 2008. Target accessibility and signal specificity in live-cell detection of BMP-4 mRNA using molecular beacons. Nucleic Acids Res 36: e30. doi:10.1093/nar/ gkn039

Robertus JD, Ladner JE, Finch JT, Rhodes D, Brown RS, Clark FC, Klug A. 1974. Structure of yeast phenylalanine tRNA at $3 \AA$ resolution. Nature 250: 546-551. doi:10.1038/250546a0

Santoro SW, Joyce GF. 1997. A general purpose RNA-cleaving DNA enzyme. Proc Natl Acad Sci 94: 4262-4266. doi:10.1073/pnas.94 .9 .4262

Santoro SW, Joyce GF. 1998. Mechanism and utility of an RNA-cleaving DNA enzyme. Biochemistry 37: 13330-13342. doi:10.1021/ bi9812221

Serebrov V, Vassilenko K, Kholod N, Gross HJ, Kisselev L. 1998. $\mathrm{Mg}^{2+}$ binding and structural stability of mature and in vitro synthesized unmodified Escherichia coli tRNA ${ }^{\text {Phe }}$. Nucleic Acids Res 26: 2723-2728. doi:10.1093/nar/26.11.2723

Shedlovskiy D, Shcherbik N, Pestov DG. 2017. One-step hot formamide extraction of RNA from Saccharomyces cerevisiae. RNA Biol 14: 1722-1726. doi:10.1080/15476286.2017.1345417

Shi H, Moore PB. 2000. The crystal structure of yeast phenylalanine tRNA at $1.93 \AA$ resolution: a classic structure revisited. RNA 6: 1091-1105. doi:10.1017/S1355838200000364

Simon MD. 2013. Capture hybridization analysis of RNA targets (CHART). Curr Protoc Mol Biol 101: 21.25.1-21.25.16. doi:10 .1002/0471142727.mb2125s101

Skoog DA, Holler FJ, Crouch SR. 2018. Principles of instrumental analysis. Cengage Learning, Boston, MA.

Stein A, Crothers DM. 1976. Conformational changes of transfer RNA. The role of magnesium(II). Biochemistry 15: 160-168. doi:10 .1021/bi00646a025

Sun SC, Dou HY, Chuang MC, Kolpashchikov DM. 2019. Multi-labeled electrochemical sensor for cost-efficient detection of single nucleotide substitutions in folded nucleic acids. Sens Actuators $B$ Chem 287: 569-575. doi:10.1016/j.snb.2019.02.073

Wang L, Yang CJ, Medley CD, Benner SA, Tan W. 2005. Locked nucleic acid molecular beacons. J Am Chem Soc 127: 1566415665. doi:10.1021/ja052498g

Yang H, Lam SL. 2009. Effect of 1-methyladenine on thermodynamic stabilities of double-helical DNA structures. FEBS Lett 583: 15481553. doi:10.1016/j.febslet.2009.04.017

Yang H, Zhan Y, Fenn D, Chi LM, Lam SL. 2008. Effect of 1-methyladenine on double-helical DNA structures. FEBS Lett 582: 16291633. doi:10.1016/j.febslet.2008.04.013

Zhou H, Kimsey IJ, Nikolova EN, Sathyamoorthy B, Grazioli G, McSally J, Bai T, Wunderlich $\mathrm{CH}$, Kreutz C, Andricioaei I, et al. 2016. $m^{1} A$ and $m^{1} G$ disrupt A-RNA structure through the intrinsic instability of Hoogsteen base pairs. Nat Struct Mol Biol 23: 803810. doi:10.1038/nsmb.3270 

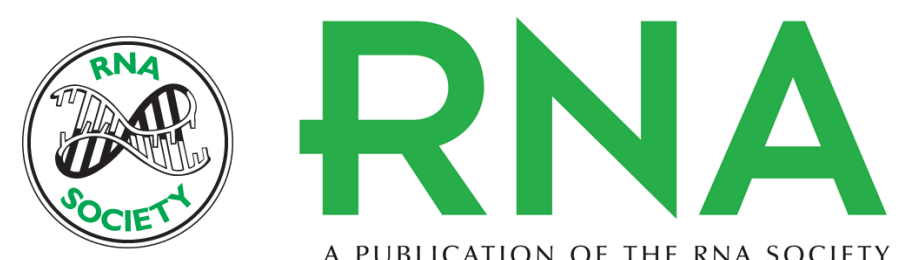

A PUBLICATION OF THE RNA SOCIETY

\section{Interrogation of highly structured RNA with multicomponent deoxyribozyme probes at ambient temperatures}

Adam J. Reed, Ryan J. Sapia, Charles Dowis, et al.

RNA 2020 26: 1882-1890 originally published online August 28, 2020

Access the most recent version at doi:10.1261/rna.074864.120

\section{Supplemental http://rnajournal.cshlp.org/content/suppl/2020/08/28/rna.074864.120.DC1 \\ Material}

References This article cites 43 articles, 6 of which can be accessed free at: http://rnajournal.cshlp.org/content/26/12/1882.full.html\#ref-list-1

Creative This article is distributed exclusively by the RNA Society for the first 12 months after the Commons full-issue publication date (see http://rnajournal.cshlp.org/site/misc/terms.xhtml). After 12

License months, it is available under a Creative Commons License (Attribution-NonCommercial 4.0 International), as described at http://creativecommons.org/licenses/by-nc/4.0/.
Email Alerting Receive free email alerts when new articles cite this article - sign up in the box at the Service top right corner of the article or click here.

To subscribe to $R N A$ go to:

http://rnajournal.cshlp.org/subscriptions 